\title{
Shell disease of Neoepisesarma mederi crabs and its associated secondary infections
}

\author{
Sharmila Joseph F.R ${ }^{\star}$, S. Ravichandran and K. Kumaravel \\ Centre of Advanced Study in Marine Biology, Faculty of Marine Sciences, Annamalai University, Parangipettai - \\ 608502, Tamil Nadu, India. \\ Accepted 8 February, 2013
}

\begin{abstract}
Shells of crabs are infected with a high prevalence of diseases than any other crustacean. Bacteria, viruses, fungi and several other pathogens influence higher percentage of shell disease in crabs. Infections in crab affected growth and metabolism and it may also lead to death. This work deals with the microscopic examination of shell diseased crabs with reference to its variation in hemocytes count, histopathology and biochemical estimation. The total heterotrophic bacterial (THB) population in normal shell was found to be $5.15 \times 10^{4} \pm 0.09$ Colony forming unit (CFU) $\mathrm{ml}^{-1}$ and THB load was noted to be slightly increased than in normal shell and the count was $5.95 \times 10^{4} \pm 0.12 \mathrm{CFU} \mathrm{ml}{ }^{-1}$ in the infected shell. The current findings suggest a positive correlation between bacterial shell disease and the secondary infection affecting hemolymph (total hemocyte count), proximate composition (protein, carbohydrate and lipid) and histopathology of the animal (gills, hepatopancreas and heart). The total hemocyte count and differential count were experimented which showed lower number of total hemocytes in infected crabs while no highly accountable difference was found in differential count. Hematology studies reported total hemocyte as $9.93 \times 10^{6} \pm 0.07$ cells $\mathrm{ml}^{-1}$ in normal and $6.525 \times 10^{6} \pm$ 0.12 cells $\mathrm{ml}^{-1}$ in shell diseased hemolymph. The level of protein, carbohydrate and lipid contents suffered a mild alteration in crabs with bacterial shell disease. Histopathology of gills had shown variations such as dilated lamellae and hemocyte accumulation (nodules), hepatopancreas showed mild difference with increased necrosis, appearance of hemocytic nodules in the hemal spaces and heart with very mere infection while no reportable changes were accomplished in muscle tissue.
\end{abstract}

Key words: Shell disease, bacteria, hematology, histopathology, biochemical composition.

\section{INTRODUCTION}

Brachyurans, support an important sport and commercial fishery along the Indian waters. They possess immense scientific, economic, and ecological value with antimicrobial (White et al., 1985), anti-leukemic (Alain et al., 2011), anti-coagulant (Preyanat et al., 2003) and cardio active properties (Fort et al., 2007). They are also used as tools in drug action mechanisms. Shell disease is a common syndrome in decapod crustaceans that cause various types of erosive lesions on the shell (Johnson, 1983; Sindermann and Lightner, 1988). High prevalence of shell disease has been associated with stressful environments, such as intensive aquaculture (Sindermann, 1990), impounded populations (Taylor, 1948), or polluted natural environments (Gopalan and Young, 1975; Young and Pearce, 1975). These shell diseases can also be considered as a biomarker for 
environmental degradation (Sindermann, 1990). Shell disease, the degradation of a crustacean's integument, is actually an external infection where a variety of microorganisms may attack the chitin of exoskeleton and has been known to affect crustaceans since 1900 (Rosen, 1970). The term shell disease was coined by Hess (1937) to describe exoskeleton lesions on the American lobster, Homarus americanus.

Histological studies have shown that gills, hepatopancreas and heart of diseased crabs were also affected significantly (Vogan et al., 2001). Although the disease is not believed to be fatal in its initial stages, death is known to result from adhesion of successive moult shells at lesion sites leading to incomplete withdrawal from exuviate at moult (Smolowitz et al., 1992). Alterations in immune reactivity within invertebrates have been shown in response to various external and artificial stimuli, including changes in temperature and salinity, pollutants (Le Moullac and Haffner, 2000), and natural or artificially induced infections (Ford et al., 1993). Vogan et al. (2001) have recently explained that severely shell diseased edible crab, Cancer pagurus display systemic haemocoelic bacterial infections in combination with damage to the gills and hepatopancreas. No specific studies in Neoepisesarma mederi crab have yet been reported which deals with shell diseases and their secondary infection in ecologically important mangrove crabs. Hence this study focuses on comparative search of secondary infection in hemocytes, biochemical composition and internal organs of bacterial shell diseased as well as disease free crabs.

\section{MATERIALS AND METHODS}

\section{Animal collection}

Crabs were collected during low tide (pre-monsoon) from Vellar estuary (Lat. $11^{\circ} 29^{\prime \prime} \mathrm{N}$ and Long. $79^{\circ} 46^{\prime \prime} \mathrm{E}$ ), South-East coast of India in sterile polythene bags using sterile forceps and subjected to experiments. After capture, both infected $(n=20)$ and un-infected $(n=20)$ crabs (females) were acclimatized to laboratory conditions (Salinity $10-34 \mathrm{ppt}$, Temperature $22-30^{\circ} \mathrm{C}, \mathrm{pH} 8.0-8.5$ ) in separate tubs.

\section{Enumeration of total heterotrophic bacterial (THB) population}

The shells of both shell diseased and disease free $N$. mederi crabs were dissected using sterile scissors and forceps. The carapace were crushed in homogenizer and serially diluted. Bacteria were isolated by pour plate method in Zobell marine agar (2216). Bacterial colonies were obtained after incubation of $24 \mathrm{~h}$ at $37^{\circ} \mathrm{C}$. The plates were examined and counted for the number of colonies per plate. The microbial load in the given sample was calculated and is expressed as colony forming units (CFU) per $\mathrm{ml}$ of the sample. Pure cultures screened from randomly isolated colonies were transferred to nutrient agar slants and stored at $4^{\circ} \mathrm{C}$ for future use.

\section{Hemocyte counts}

Hemolymph was collected from both disease free and shell diseased $N$. mederi crabs from walking limp (pereiopods 2 to 5 ) using sterile gauge needle in eppendorf tubes. The hemolymph was diluted with sodium citrate buffer $(\mathrm{pH}-4.6)$ in the ratio of 1:5. Hemolymph stain was prepared using Giemsa stain (5:1 dilution) and observed under microscope for hemocyte count (Vogan and Rowley, 2002).

\section{Total hemocyte count}

Total hemocyte counts were established from hemolymph of both normal and infected $N$. mederi by an improved Neubauer hemocytometer using the formula; Cell count $=\mathrm{N} \times \mathrm{D} / \mathrm{A} \times 10 \times 10^{3}$ cells $/ \mathrm{ml}$ where, $\mathrm{N}$ is the total number of cells counted; $\mathrm{D}$ is the dilution of hemolymph; $\mathrm{A}$ is the total area counted and Factor 10 to convert area into volume (in $\mu \mathrm{l})$.

\section{Differential count}

Differential counts were conducted on slides prepared by $100 \mu \mathrm{l}$ of diluted cell suspension $\left(1 \times 10^{4}\right.$ cells $\left.\mathrm{ml}^{-1}\right)$. The percentage of different cells was determined by the formula; Number of a particular hemocyte type / Total number of all types of hemocytes $x$ 100.

\section{Biochemical composition of crab tissue}

Tissues were collected from each crab separately after dissection using sterile scissors and subjected to proximate analysis of protein, carbohydrate and lipid using standard methods of Lowry et al. (1951), Dubois et al. (1956) and Folch et al. (1956) respectively.

\section{Histological examination of crab tissue}

To determine whether shell disease intrudes structural changes in internal tissues like gills, hepatopancreas, heart and muscle tissue, and both un-infected and infected crabs' histological studies were conducted. The animals were anesthetized by ketamine vapours and the anesthetized animals were immediately dissected. Gills, heart, hepatopancreas and muscle tissue were kept in separate sterile slides and subjected to section cutting into 2 to 3 regions per block. The sections were washed with sterile distilled water and stained with eosin. The stained sections were examined histologically using 100X microscope.

\section{Data analysis}

Data were treated statistically by one way analysis of variance (ANOVA) and t-test (Two-Sample Assuming Equal Variances) to test the significance. Results were considered significant if $P \leq 0.05$.

\section{RESULTS}

\section{Enumeration of total heterotrophic bacterial (THB) population}

The total number of bacteria in shells of infected and un- 

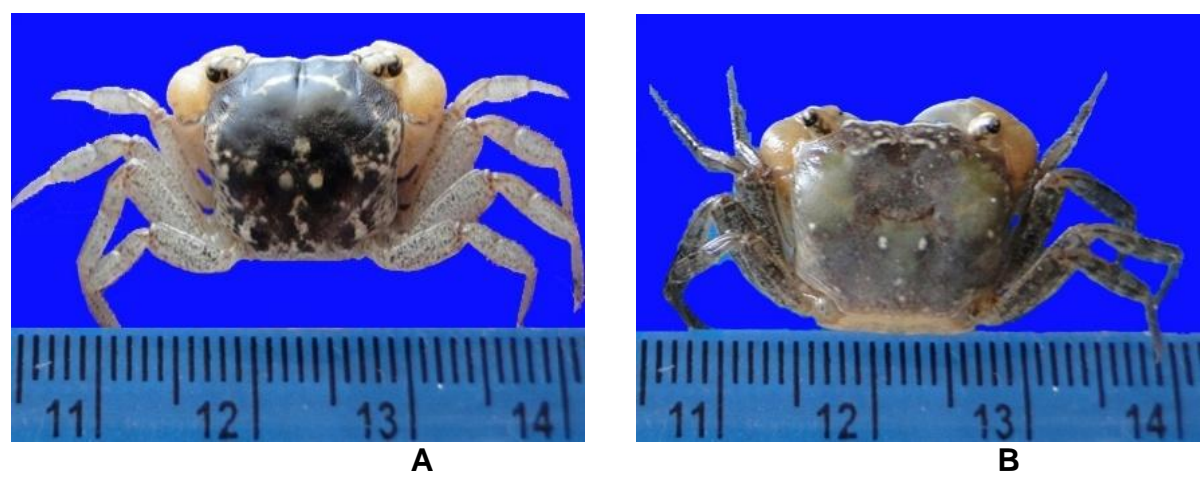

Figure 1. Study animal. A - Normal crab; B - Infected crab.

infected animals was estimated after isolation and growth on nutrient agar plates incubated at $37^{\circ} \mathrm{C}$. The total heterotrophic bacterial (THB) population in normal shell was found to be $5.15 \times 10^{4} \pm 0.09 \mathrm{CFU} \mathrm{ml}^{-1}$ and THB load was noted to be slightly increased than in normal shell (Figure $1 \mathrm{~A}$ ) and the count was $5.95 \times 10^{4} \pm 0.12 \mathrm{CFU} \mathrm{ml}^{-1}$ in the infected shell (Figure 1B). The bacteria identified in infected shell were Aeromonas, Pseudomonas, Flavobacterium and Bacillus, three (Aeromonas, Pseudomonas and Bacillus) of which were found to be absent in the normal shells. Alcaligens, Flavobacterium, Alteromonas and Photobacterium were identified in normal shells.

\section{Hemocyte classification}

In Neoepisesarma mederi, four different hemocyte types were recognized based on their nuclear morphology, refractile nature of granules and staining characteristics with Giemsa stain (Figure 2).

\section{Hemocyte counts}

The circulating hemocytes for all un-infected $(n=20)$ were found to be $9.93 \times 10^{6} \pm 0.07$ cells $\mathrm{ml}^{-1}$ whereas for all infected crabs $(n=20)$, the total circulating hemocyte count was $6.525 \times 10^{6} \pm 0.12$ cells $\mathrm{ml}^{-1}$. Using Giemsa staining method, hemogramme was observed to consist of almost similar number of differential hemocytes both in un-infected and infected $N$. mederi crabs which were recorded as $41.38 \pm 1.19 \%$ (normal) and $41.3 \pm 0.02 \%$ (infected) hyaline cells $(\mathrm{H}) ; 26.61 \pm 1.98 \%$ (normal) and $26.58 \pm 1.2 \%$ (infected) basophilic granular (BG) cells; $22.06 \pm 2.92 \%$ (normal) and $21.87 \pm 1.98 \%$ (infected) basophilic/eosinophilic granular cells (BEG) and $10.54 \pm$ $2.4 \%$ (normal) and $10.02 \pm 1.9 \%$ (infected) eosinophilic granular (EG) cells. One way analysis of variance done showed that total hemocytes count among un-infected and infected crabs differed significantly $(P<0.05)$ while differential count differed insignificantly $(P>0.05)$.

\section{Proximate composition}

\section{Protein}

The content of total protein in wet tissue of experimental crabs was estimated by spectrometry at $540 \mathrm{~nm}$ and calibration curve. The protein content was found to be $8.494 \pm 0.876 \%$ in un-infected healthy crabs and $6.438 \pm$ $0.764 \%$ in infected crabs. One way analysis of variance showed that protein content among un-infected and infected crabs differed significantly $(\mathrm{P}<0.05)$.

\section{Carbohydrate}

The level of total carbohydrate in wet tissue of experimental crabs was estimated by spectrometry at $490 \mathrm{~nm}$ and calibration curve. The total carbohydrate level was found to be $0.8008 \pm 0.029 \%$ in un-infected crabs and $0.654 \pm 0.025 \%$ in infected crabs. One way analysis of variance showed that carbohydrate content among un-infected and infected crabs differed significantly $(\mathrm{P}<0.05)$.

\section{Lipid}

The percentage of total lipid in wet tissue of experimental crabs was estimated and found to be $2.8 \pm 0.01 \%$ in uninfected crabs and $1.926 \pm 0.07 \%$ in infected crabs. One way analysis of variance showed that lipid content among un-infected and infected crabs differed significantly $(\mathrm{P}<0.05)$.

\section{Histopathology}

\section{Gills}

A pair of gills was present on either side of the branchial chamber in Neoepisesarma mederi. The structure consisted of pairs of flattened lamellae branching from 


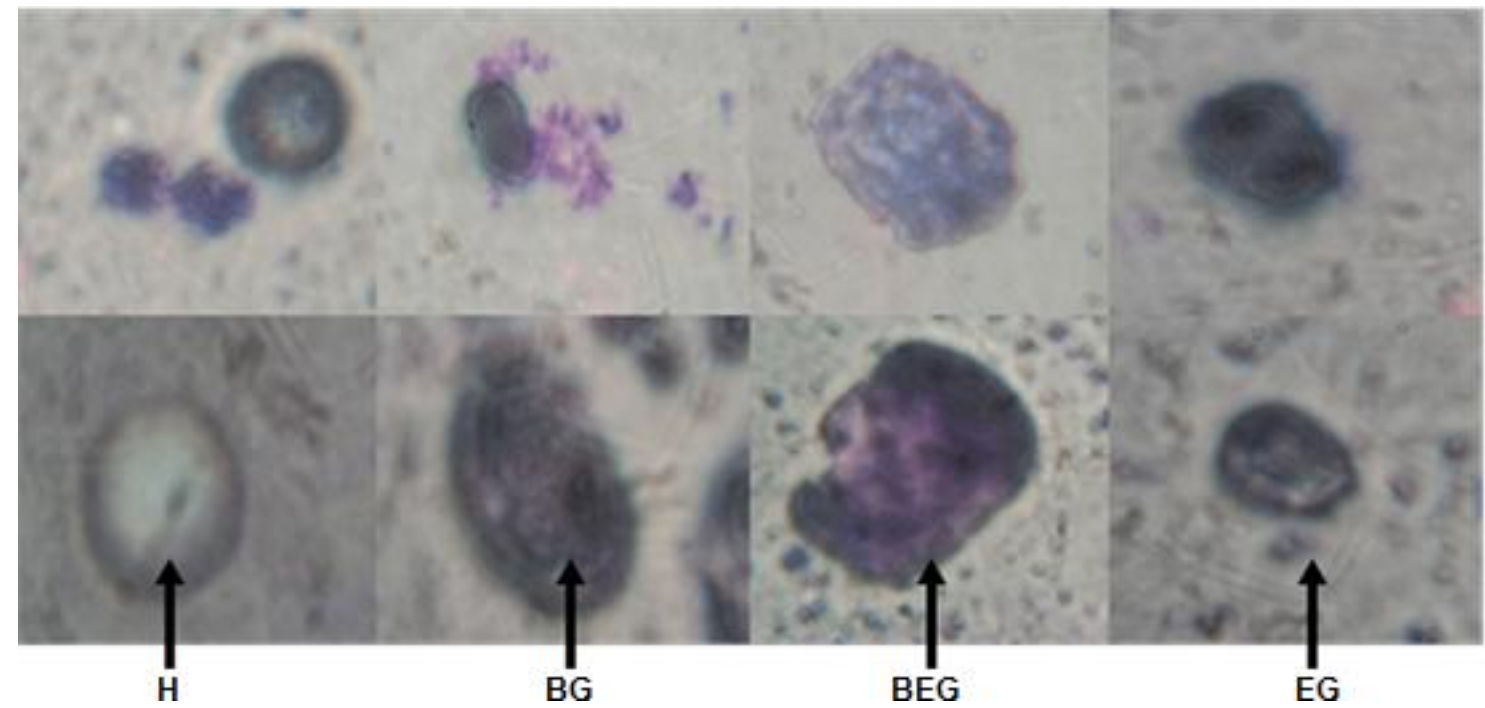

Figure 2. Hemocyte classification of $N$. mederi species. H - Hyaline cells; BG - Basophilic granular cells; BEG - Basophilic/Eosinophilic granular cells; EG - Eosinophilic granular cells.

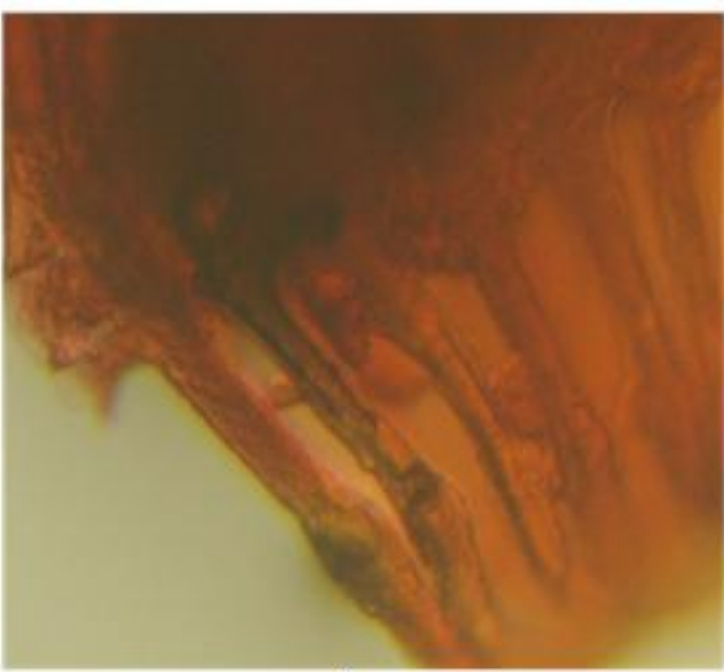

A

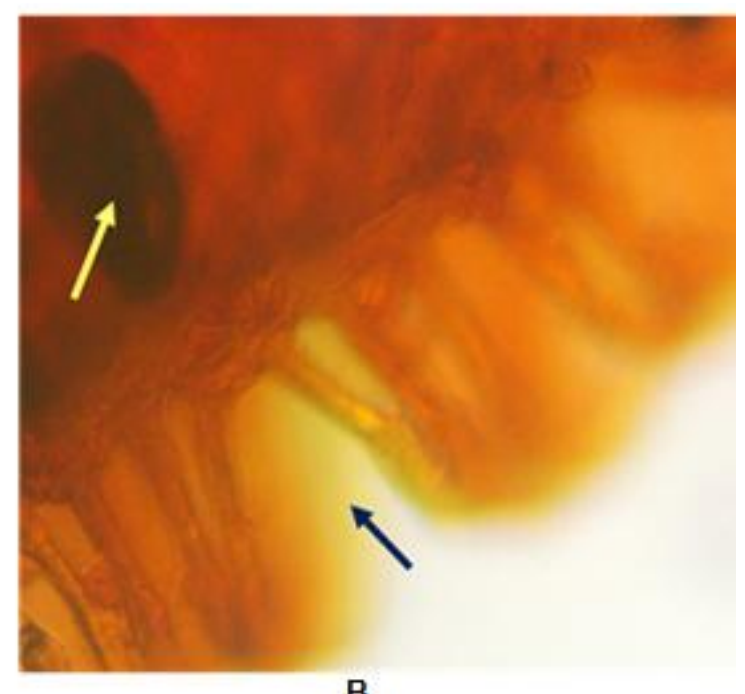

B

Figure 3. $100 \mathrm{X}$ micrographs of gills of $N$. mederi. A) Section of a normal gill B) Section of infected gill showing hemal nodules and dilated lamella.

the central branchial stem, which had afferent and efferent hemal channels on each and each lamella was covered by a thin epithelium. Distinct histological changes in the gill were observed in crabs with shell disease. The lamellae were dilated and hemocyte accumulation (nodules) was also observed (Figure 3).

\section{Hepatopancreas}

As the apparent severity of shell necrosis increased, hemocytic nodules appeared in the hemal spaces (Figure
4). In the most severely affected animals, a massive destruction of epithelial cells was observed in some areas. A distinct lack of free hemocytes was also observed in the inter-tubular spaces.

\section{Heart}

Though no structural changes were observed in the myocardium or epicardium between control and shell diseased crabs but changes were observed in the number of hemocytic nodules (Figure 5). 


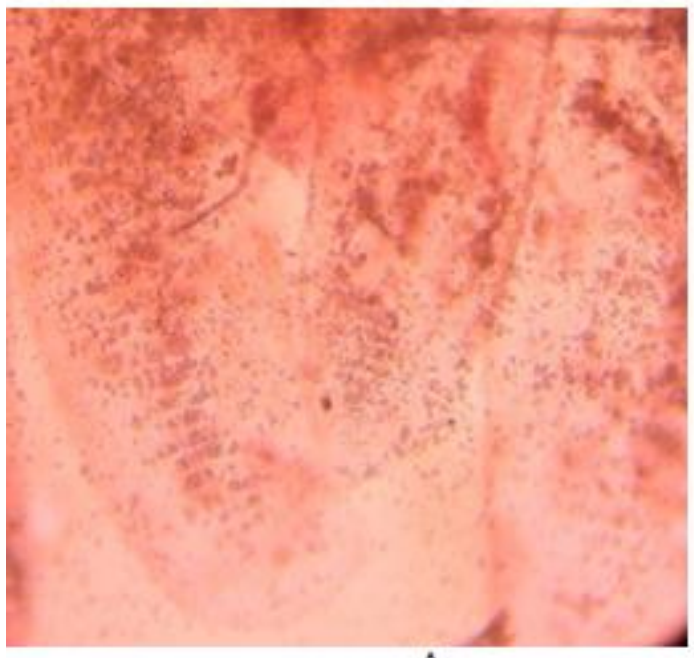

A

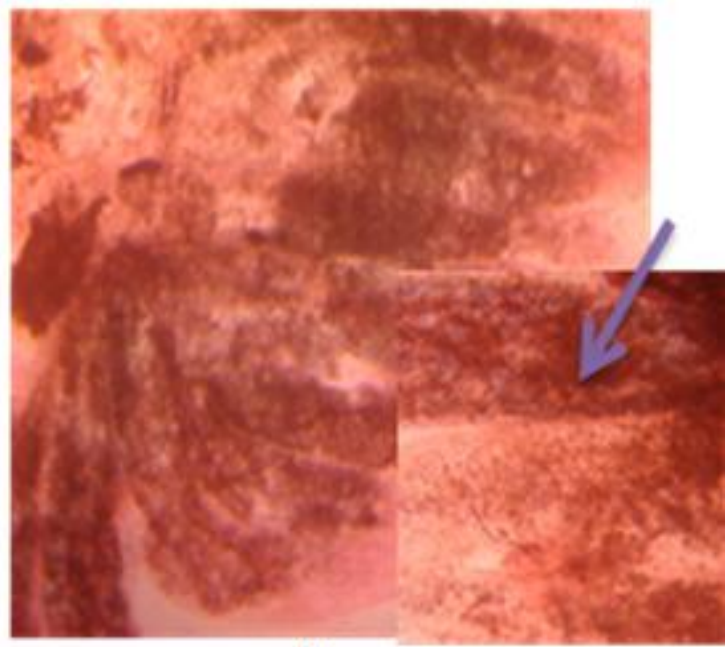

B

Figure 4. Section of hepatopancreas of $N$. mederi A) Normal hepatopancreas with free hemocytes B) Infected hepatopancreas showing hemocytic nodules in hemal spaces and lack of free hemocytes (inner image).

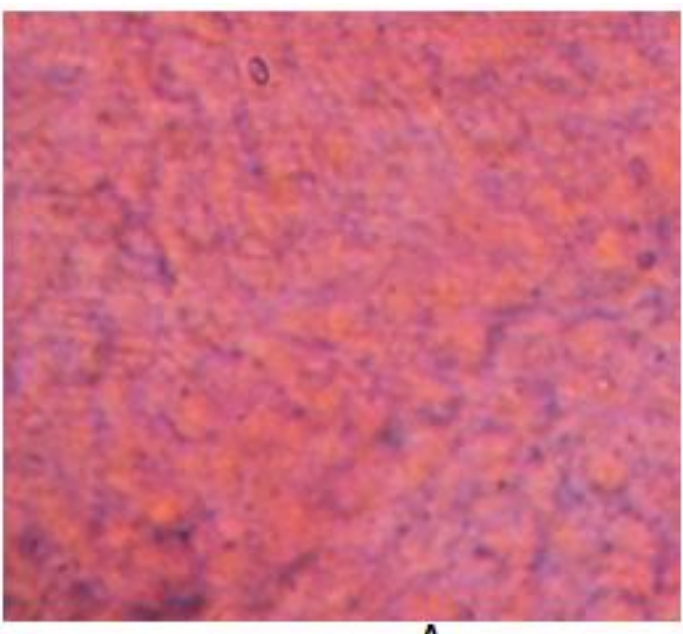

A

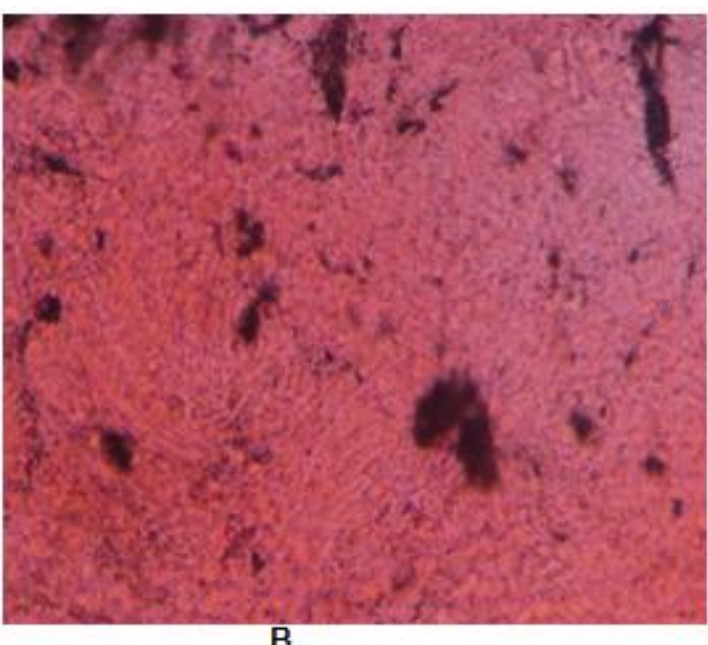

B

Figure 5. Section of heart A) Normal B) Infected showing hemal nodules (clumping of hemocytes).

\section{Muscle tissue}

No recordable alterations were observed in the muscle tissue of shell infected N. mederi (Figure 6).

\section{DISCUSSION}

Crabs are continuously affected by environmental fluctuations and management practices such as handling, crowding, transporting, fluctuating temperatures and poor water quality. All of these factors can impose candidate stress on the homeostatic mechanisms of crab rendering them susceptible to a wide variety of pathogens (Wang, 2011). Mu et al. (2009a, b), Meng et al. (2010) and more other researchers have reported aspects of crab immune system. Circulating hemocytes play an extremely important role in the defense reactions by phagocytosis, hemocyte clumping, the production of reactive oxygen metabolites and the release of microbicidal proteins (Smith and Chisholm, 1992, 2001; Smith et al., 2003). In addition, gills serve another important role in the immune response (Johnson, 1976a, b; White et al., 1985; Martin et al., 2000; Burnett et al., 2006). Johnson (1976a) provided histological evidence that nodule formation in response to stress-induced bacteremia in blue crabs might have adverse effects on gill function, including distention of gill lamellae and disruption of haemolymph flow.

Initially it was thought bacterial infection to be restricted 


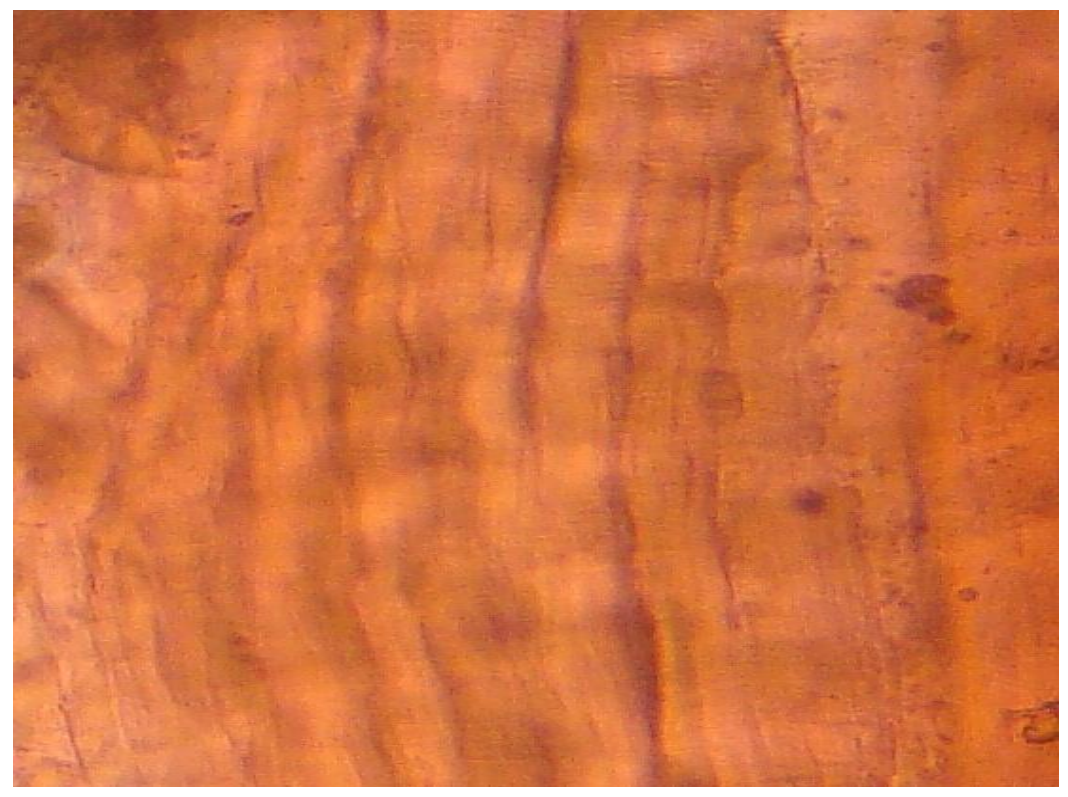

Figure 6. Section of muscle tissue of $N$. mederi.

to the exterior surfaces of the exoskeleton, recent studies showed that shell disease is not a disease caused by a single pathogen and solely restricted to the exoskeleton (Wang et al., 2011). Though the findings of Vogan and Rowley (2002) in the edible crab Cancer pagurus explains there is no significant correlation between bacterial shell infection and hemocyte count, in a previous study of Vogan et al. (2001), individuals exhibiting shell disease were shown to have internal infections. There was a linear relationship between the bacterial load and the severity of the disease. This study also revealed breakdown of the hepatopancreas and damage to gills associated with nodule formation (hemocyte clumping). Stage and gender of the animal also brings about considerable difference in their hemocyte count (Depledge and Bjerregaard, 1989; Horn and Kerr, 1963). The present investigation dealt with the hematology studies with female crabs within a range carapace width of 6 to $9 \mathrm{~mm}$. Significant difference in the total hemocyte count and insignificant difference in differential count was observed between un-infected and infected $N$. mederi crabs.

Eric Floreto (2000) showed significant differences in the biochemical profiles of the various tissues between healthy and shell-disease affected lobsters. Biochemical constituents in crabs are known to vary with season, size of the animal, stage of maturity, temperature, availability of food etc. Nutrition has a direct relationship with biochemical composition of the animal (Manivannan et al., 2010). Ravichandran and Kannupandi (2004) reported biochemical composition of five mangrove crab Sesarma. brockii, S. andersoni, S. plicatum, Metapograpsus messor and $M$. maculatus among the species M. messor showed maximum proximate composition. All the crabs observed in the present study were females (brood and un-brood) and it is quite interesting that no infected male was identified. Results show a mild but reportable decrease in protein, carbohydrate and lipid level in shell diseased $N$. mederi than disease free controls. The results above could definitely show a slight consideration in biochemical variation and it's relation towards shell disease. It can be thought that the alteration in proximate composition of protein, carbohydrate and lipid of infected animals may be due to an unpredictable change in its feeding habit during the onset of bacterial attack.

The presence of melanised nodules in gills, heart and hepatopancreas suggest systematic bacterial infections in these animals (Johnson, 1976a, b; Smith and Ratcliffe, 1980). The breaches observed in lamellar epithelium combined with hemocytic infiltration and nodule formation around these foci identify a potential route of invasion by micro-organisms. In decapods, the epidermal cells of the gill lamellae, unlike the rest of the integument, possess only an ultra-thin covering of chitinous cuticle. Thus, although this thin covering is more vulnerable than the rest of the integument, its breach would still have to be through active chemical attack (Victor, 1993, 1994; Soegianto et al., 1999a), abrasive injuries or the extracellular enzymatic activities of micro-organisms (Lightner and Fontaine, 1975). Morado et al. (1988) showed erosion of the arthrodial membrane between the propodus and pereiopods of Dungness crabs Cancer magister that coincided with the appearance of nodules in the gills. Unexpectedly, the severity of shell disease in Cancer pagurus did not result dramatic changes to the 
majority of immune parameters tested, including total hemocyte counts (Vogan and Rowley, 2002). Vogan et al. (2002) found that extracellular products (ECP) produced with shell disease could cause rapid death of the crab upon injection. The present study found distinct changes in histology of the gill displaying nodules which may be formed due to the lack of free running hemocytes. The disease can lead the animal to varying consequences like defective oxygen transport. Oxygen transport may be greatly affected as it is carried out by gills where hemocyte clumping was noticed in shell diseased animals. The lamellae were found to be dilated. Severe internal damage is associated with crabs showing highest amount of external damage in regions surrounding the branchial chambers. The carapace of the infected $N$. mederi was found to be too delicate when compared to normal ones.

Bowser et al. (1981) reported vacuole formation in hepatopancreas which resulted after the intra-hemocoelic injection of Vibrio spp. Pathogenecity of Vibrio harveyi was studied by Robertson et al. (1998) in Penaeus vannamei larvae and the results showed necrotic bundles in hepatopancreas of the infected animal. The present study also supports previous studies with necrotic bundles found scattered throughout the hepatopancreas of the shell-diseased $N$. mederi. Liberation of bacterial toxins may disturb the integration of hepatopancreas resulting in autolysis of tubules. Vogt (1997) support this through his findings in Palaemon elegans in which it was believed that exotoxin from Gram-negative bacteria caused destruction of hepatopancreas. Hemocytic nodules in hemal spaces and distinct lack of free hemocytes were also observed in hepatopancreas of shell-diseased $N$. mederi crabs.

Cardiac lumen of shell-diseased crabs showed number of hemocytic nodules while no structural alteration was observed. Though studies by Vogan et al. (2001) show similar type of result in the edible crab, Cancer pagurus it may not be inferred that the occurrence of nodules were found due to the impact of shell-disease. They may be formed due to the varied procedures followed in the histology studies. Further studies have to be done to confirm the results with heart. No previous results were found to suggest a muscle histological alteration coinciding with shell-disease of crustaceans. Muscles suffered no structural or observable changes also in the present histological investigation of bacteria infected $N$. mederi animals.

In conclusion, shell disease is well identified to cause secondary infection bringing alteration in the normal histology of the animal. Therefore, potential approaches should be designed such that a single compound or a strategy is sufficient for the development of immune activity in crab in order to control shell diseases as this induces loss of immunity as a result of its secondary infection. The influence of shell-disease and mortality of $N$. mederi has yet to be studied and it is suggested that lethal effects may depend on the type of infected microbe and its rate and degree of infection in the animal.

\section{ACKNOWLEDGEMENT}

Authors are thankful to the University Grants Commission, Government of India for the financial support.

\section{REFERENCES}

Alain D, Lucie B, Linda S, Yves P, Laurent B (2011). Demonstration of in vitro anticancer properties of peptide fractions from a snow crab by-products hydrolysate after separation by electrodialysis with ultrafiltration membranes. Sep. Purif. Technol. 78(3):321-329.

Bowser PR, Rosemark R, Reiner CR (1981). A preliminary report of vibriosis in cultured American lobsters, Homarus americanus. J. Invertebr. Pathol. 37:80-85.

Burnett LE, Holman JD, Jorgensen DD, Ikerd JL, Burnett GK (2006). Immune defense reduces respiratory fitness in Callinectes sapidus the Atlantic Blue Crab. Biol. Bull. 211:50-57.

Depledge $\mathrm{MH}$, Bjerregaard $\mathrm{P}$ (1989). Hemolymph protein composition and copper levels in decapods crustaceans. Helgol Meeresunters 43:207-223.

Dubois M, Gilles KA, Hamilton JK, Rebers PA, Smith F (1956). Colorimetric method for determination of sugars and related substances. Anal. Chem. 28:350-356.

Eric Floreto AT, Deanna Prince L, Paul Brown B (2000). The biochemical profiles of shell-diseased American lobsters, Homarus americanus Milne Edwards. Aquaculture 188:247-262.

Folch JM, Lees Stanely GHS (1956). A simple method for the isolation and purification of total lipids from animal tissues. J. Biol. Chem. 226:497-509.

Ford SE, Kanaley SA, Littlewood DTJ (1993). Cellular responses of oysters infected with Hap losporidium nelson, changes in circulating and tissue-infiltrating haemocytes. J. Invertebr. Pathol. 61:49-57.

Fort TJ, Crescioni KG, Agricola HJ, Vladimir Brezina, Miller MW (2007). Regulation of the Crab Heartbeat by Crustacean Cardioactive Peptide (CCAP): Central and Peripheral Actions. J. Physiol. 97(5):3407-3420.

Gopalan UK, Young JS (1975). Incidence of shell disease in shrimps of the New York Bight. Mar. Pollut. Bull. 6:149-153.

Hess E (1937). A shell disease in lobsters Homarus americanus caused by chitinovorous bacteria. J. Biol. Board Can. 3:358-362.

Horn EC, Kerr MS (1963). Hemolymph protein and copper concentrations of adult blue crabs Callinectes sapidus Rathburn. Biol. Bull. 125:499-507.

Johnson PT (1976a). Bacterial infection in the blue crab, Callinectes sapidus course of infection and histopathology. J. Invertebr. Pathol. 28:25-36

Johnson PT (1976b). An unusual microorganism from the blue crab, Callinectes sapidus. In: Proceeding of the First International Colbquium on Invertebrate Pathology. Kingston, Ontario, p. 316.

Johnson PT (1983). Diseases caused by viruses, bacteria, rickettsia and fungi. The Biology of Crustacea 6:1-78.

Le Moullac G, Haffner $P$ (2000). Environmental factors affecting immune responses in Crustacea. Aquaculture 191:121-131.

Lightner DV, Fontaine CT (1975). A mycosis of the American lobster, Homarus americanus caused by Fusarium sp. J. Invertebr. Pathol. 25:239-245.

Lowry OH, Rosenbrough NJ, Farr AL, Randall RJ (1951). Protein measurement with the Folin Phenol Reagent. J. Biol. Chem. 193:265275.

Manivannan K, Sudhakar M, Murugesan R, Soundarapandian P (2010). Effect of feed on the biochemical composition of commercially important mud crab Scylla tranquebarica Fabricius (1798). Int. J. Anim. Vet. Adv. 2(1):16-20.

Martin GG, Quintero M, Quigley M, Khosrovian H (2000). Elimination of 
sequestered material from the gills of decapods crustaceans. J. Crustacean Biol. 20:209-217.

Meng Q, Li W, Liang T, Jiang X, Gu W, Wang W (2010). Identification of adhesion-like protein ALP41 from Spiroplasma eriocheiris and induction immune response of Eriocheir sinensis. Fish Shellfish Immunol. 55:245-250.

Morado JF, Sparks AK, O'Clair CE (1988). A preliminary study of idiopathic lesions in the Dungeness crab, Cancer magister, from Rowan Bay, Alaska. Mar. Environ. Res. 26:311-318.

Mu C, Zhao J, Wang L, Song L, Zhang H, Li C, Qu L, Gai Y (2009a). Molecular cloning and characterization of peroxiredoxin 6 from Chinese mitten crab Eriocheir sinensis. Fish Shellfish Immunol. 26:821-827.

Mu C, Zhao J, Wang L, Song L, Zhang H, Li C, Qiu L, Gai Y, Cui Z (2009b). A thioredoxin with antioxidant activity identified from Eriocheir sinensis. Fish Shellfish Immunol. 26:716-723.

Preyanat V, Warayut S, Watchara K, Damrus S, Prachya K (2003). Anticoagulant activities of the chitosan polysulfate synthesized from marine crab shell by semi-heterogeneous conditions. Sci. Asia 29:115-120.

Ravichandran S, Kannupandi T (2004). Biochemical changes in decomposing leaves and crabs of Pichavaram mangroves. Biochem. Cell. Arch. 4(2):79-86.

Robertson PAW, Cauldron J, Carrerea L, Stark JR, Zhermant M, Austin B (1998). Experimental Vibrio harveyi infections in Penaeus vannamei larvae. Dis. Aquat. Org. 32:151-155.

Rosen B (1970). Shell disease of aquatic crustaceans. In: Snieszko SF (ed) A symposium on diseases of fishes and shellfishes, Spec. Publ. No. 5. American Fisheries Soc, Washington DC. pp. 409-415.

Sindermann CJ (1990). Principal diseases of marine fish and shellfish. Academic press New York, NY, 2:521.

Sindermann CJ, Lightner DF (1988). Disease diagnosis and control in North American Marine Aquaculture, 2nd edn. Elsevier, New York, NY.

Smith VJ, Brown JH, Hauton C (2003). Immunostimulation in crustaceans: does it really protect against infection? Fish Shellfish Immunol. 15:71-90.

Smith VJ, Chisholm JRS (1992). No cellular immunity in crustaceans. Fish Shellfish Immunol. 2:1-31.

Smith VJ, Ratcliffe NA (1980). Cellular defence reactions of the shore crab, Carcinus maenas: In vivo hemocytic and histopathological responses to injected bacteria. J. Invertebr. Pathol. 35:65-74.
Smolowitz RM, Bullis RA, Abt DA (1992). Pathological cuticular changes of winter impoundment shell disease preceding and during intermoult in the American lobster, Homarus americanus. Biol. Bull. 183:99-112.

Soegianto A, Charmantier DM, Trilles JP, Charmantier G (1999a). Impact of cadmium on the structure of the gills and epipodites of the shrimp Penaeus japonicus Crustacea: Decapoda. Aquat. Living Resour. 12:57-70.

Taylor CC (1948). Shell disease as a mortality factor in the lobster. State of Marine Dept of Sea and Shore Fisheries, Fisheries Circular No 4.

Victor B (1993). Responses of hemocytes and gill tissues to sublethal cadmium chloride poisoning in the crab Paratelphusa hydrodomous (Herbst). Arch. Environ. Contam. Toxicol. 24:432-439.

Victor B (1994). Gill tissue pathogenicity and hemocyte behavior in the crab Paratelphusa hydrodomous exposed to lead chloride. J. Environ. Sci. Health. 29A:1011-1034.

Vogan CL, Costa-Ramos C, Rowley AF (2001). A histological study of shell disease syndrome in the edible crab, Cancer pagurus. Dis. Aquat. Organ. 47:209-217.

Vogan CL, Costa-Ramos C, Rowley AF (2002). Shell disease syndrome in the edible crab, Cancer pagurus-isolation, characterization and pathogenicity of chitinolytic bacteria. Microbiology 148:743-754.

Vogan CL, Rowley AF (2002). Effects of shell disease syndrome on the hemocytes and humoral defences of the edible crab, Cancer pagurus. Aquaculture 205:237-252.

Vogt G (1997). Hepatopancreatic brush border lysis (HBL): a new bacterial disease of the shrimp Palaemon elegans. Dis. Aquat. Org. 29:151-155.

Wang W (2011). Bacterial diseases of crabs: A review. J. Invertebr. Pathol. 106:18-26.

White KN, Ratcliffe NA, Rossa M (1985). The antibacterial activity of haemocyte clumps in the gills of the shore crab Carcinus maenas. J. Mar. Biol. Assoc. UK. 65:857-870.

Young JS, Pearce JB (1975). Shell disease in crabs and lobsters from the New York Bight. Mar. Pollut. Bull. 6:101-105. 